\title{
Canadian Multiculturalism Ideology: mere tolerance or full acceptance
}

\author{
Laverne M. Lewycky \\ Adantic Baptist University
}

\section{Introduction}

September 11, 2001 will forever be etched in the memory of Canadians who were deeply affected by the events of that day. This cataclysmic occurrence had a pivotal place not only upon the private troubles of those directly related but also upon the public issues and the consequent public policies of all of us who may not have been as directly touched. Such a life-changing experience will impinge upon the politics of our entire nation. The terrorist act was a political statement at one level which must be addressed politically as well. It is noteworthy, given this context of the terrorist attack in the nation to the South, that October 8, 2001 represented the thirtieth anniversary of the political declaration of multiculturalism as a public state policy within Canada. What difference does the official policy discourse and ideology of multiculturalism make in the political response to the ethnocultural and racial diversity within and without its national borders?

This three-and-a-half-decade milestone in Canadian history along with Canada's new government affords a timely opportunity to examine the memory of the past, to determine its place in today's society as well as reflect on the future politics of multiculturalism in ethnicizing the Canadian nation. The 1971 political announcement by the Liberal Prime Minister Pierre Elliott Trudeau ushered in and institutionalized a new process of Canarlian ethnicizing that contrasted to a bilingual and a bicultural vision of the previous decade as well as the contrasting melting pot ideology. Interestingly, this announcement was made a day before the Prime Minister was to address the Ukrainian Canadian Congress in Winnipeg. The political expediency of and political pressure on the Prime Minister has been often noted by scholars. The minority groups themselves, in this case the Ukrainians, have had a role in pushing the ideology of multiculturalism into an inclusive full acceptance of rather than mere tolerance for minorities in Canadian society. The transformation of the policy emerged in the changing political, economic and ideological context of the day. Subsequently, the 1980s witnessed the adoption of Section 27 into the Canadian Constitution, under the last political parliamentary mandate of Liberal Prime Minister Trudeau, which assured the preservation and the enhancement of the multicultural heritage of Canadians.

The continued attention of Parliament in ethnicizing the nation was manifest in several ways. The 1984 Equality Now! Report and the 1987 Multiculturalism: Building the Canadian Mosaic parliamentary report both recommended institutionalization of the ethnicizing policy into an act. Accordingly, parliamentarians themselves have played a 
significant role in pushing multiculturalism ideology towards a more inclusive full acceptance of diversity in Canadian society as a national public policy. The Canadian Multiculturalism Act was proclaimed in 1988 under the auspices of the new Conservative Prime Minister Brian Mulroney. The bipartisanship participation of the Liberals and the Conservative parties, along with that of the third and other parties in parliament encouraged the embracing of a wider notion of multiculturalism ideology as a national policy and practice. This paper examines political developments in the managing of Canadian diversity and the resulting new paradigms for ethnicizing the nation as we have embarked into a new millennium. I would suggest that tracing the history in the evolution and transformation of multiculturalism as a state policy (Lewycky, 1992) offers an evaluation of the ideological strategy of acceptance and good will for dealing with the diversity of ethnocultural groups as well as visible minority groups within Canadian society. The tem visible minorities has become a somewhat unique Canadian label for all and any minority groups within Canada who are not white. The visible minority nomenclature incorporates all the sociological connotations the label implies as to expeniences of overt and covert prejudice and individual, group or institutional discrimination that these Canadians have experienced. Lessons of the past can provide for us a direction for the future as well as models for comparative democtacies.

\section{Melting Pot and Mosaic}

The multiculturalism ideological strategy of open full acceptance in contrast to the previous objective of mere tolerance for managing the ethnocultural diversity of groups within Canada has its roots in the political programs which were reflected in the early Canadian metaphors of a melting pot and a mosaic. Palmer (1976) outlined three distinct ideological perspectives in the first century of Canada's history for managing the 'other' ethnic groups: Anglo-conformity, melting pot, and cultural pluralism. These match three major waves of European immigration into Canada: 1900-1914, 1919-1939, and post World War II immigration (O'Bryan, Reitz and Kuplowska, 1976:6). The level of tolerance for the 'other' progressively increased and was reflected in the changing metaphors of the mosaic. Frye (1963) has suggested that with an ectucated imagination we discover we live in two different worlds, 'the world we live in and the world we want to live in.' This applies to the hegemonic notion of tolerance in early Canadian society.

The Canadian father of social work, J.S. Woodsworth embodied these two ideas in his two serninal books, Strangers Within Our Gates and My Neighbour, at the tum of the twentieth century when Canada invited its first major wave of European migration. Frye (1982) has suggested that the Westem world operates within a mythological universe that is a great code that is our ideological legacy especially as reflected in the literature of Great Britain. Victor Hugo expressed the same viewpoint when he said, "England has two books: one which she made; the other which made her - Shakespeare and the Bible." 
(Brown,1979:7) It is out of this worldview in the Canadian era of Anglo-conformity that we find the founder of a political party in Canada offering his version of tolerance towards the other ethnocultural groups who were coming to the prairies to settle in the agricultural hinterlands and cities of the West. His earlier idea and value of tolerance finds its roots in the Old Testament scriptures where the Israelites were to be welcoming of the foreigners and "strangers within their gates". His subsequent value of full open acceptance finds its roots in the biblical story of the Good Sarnaritan who becomes a tue neighbour to someone who needs him. We can note the progression from mere tolerance to the subsequent full open acceptance in the metaphors of a stranger who becomes a neighbour.

The ideological legacy of mere tolerance is also reflected in the metaphors of the melting pot and the mosaic between the two world wars. The melting pot metaphor was never as dominant an ideology in Canada as it was in the United States from where it was transported. For example, Henry Ford's English school graduation cercmony incorporated graduates wearing old world costumes who strolled off a huge immigrant ship into a huge melting pot and emerged wearing American clothes and waving American flags (Palmer and Troper, 1973:18). This tolerance included a caveat that all immigrants must eventually be assimilated into mainstearn American life and values. In contrast, the Canadian notion of tolerance and the prototype of acceptance used the melting pot metaphor to argue against excluding certain immigrants from Canada as undesirables. The Canadian melting pot envisioned a new Canadian homo sopiens who blended biologically and culturally.

Because the Canadian value of tolerance was strong, the melting pot metaphor was easily replaced by the mosaic. Interestingly enough it is an American, Victoria Hayward (1922) whose observations led her to label Canada as being a mosaic. The mosaic metaphor which conveys a proto-notion of acceptance was reinforced by Kate Foster (1926) and John Murray Gibbon (1938) during this second major era of Canadian immigration. Like Woodsworth, Foster's Y.M.C.A. manual of information for social workers attempted to foster tolerant reciprocal relationships between foreign and native-bom Canadians.

Gibbon's (1938) series of ten radio programs traced the contribution to the building up of the nation of Canada by each ethnic group. He believed 'in trying to preserve for the future Canadian race the most worthwhile qualities that each racial group has brought with it'. An important project, for Gibbon, is to 'discover, analyze and perfect the cements which may best hold the coloured slabs (of the mosaic) in position'. He concludes with an illustration of a folk festival as being the epitome of a cemented mosaic and the role the training provided in Canadian schools can have as the finest and the strongest cement for the Canadian Mosaic.

In the era of ethnic cultural pluralism discourse during the third wave of immigration into Canada, immigrants after World War II brought a different set of sociocultural characteristics than previously even if they had emigrated from the same countries. They had a higher level of ectucation and technological skills and were more urban-oriented. As demonstrated in their submissions to the Royal Commission on Bilingualism and 
Biculturalism (1970), these post-war immigrants were not willing to accept the limitations that the Canadian stuctures imposed to their integration. They were unsatisfied with the notion of mere tolerance but wanted full acceptance into Canadian society. In fact, so strong were the objections of Commissioner Professor J. B.Rudnyckyj that he even attached a minority report to the Royal Commission's Book IV final report. The government's response to the B \& B Commission's report eventually led to the Prime Minister Trudeau 1971 political pronouncement of a multiculturalism policy.

In the post World War II period, the earlier picture of a hamonious and tolerant Canadian mosaic, where there is equality among the various panels of the mosaic was also challenged by John Porter (1965). His classic book, The Vertical Mosaic, documents the lack of acceptance, inequality and the ethnic stratification in Canadian society. Thus we have a debate developing among many subsequent scholars. The potency of Porter's critique and the static imagery of the mosaic panels may have been the Achilles heal for the metaphor of the mosaic not becoming an enduring metaphor for the values of tolerance that are cherished in Canadian society. However, to a certain extent the mosaic metaphor does persist. Dreidger (1978) revived the mosaic analogy by drawing upon the analysis of the 1971 census by Valloe and de Vries in proposing the 'regional mosaic' of ethnic groups within Canada. In subsequent analysis, Driedger $(1987,1989)$ has incorporated the inequalities that persist in Canadian society into his mosaic in spite of the value of mere tolerance that a mosaic conveys.

\section{Mosaic to Multiculturalism}

Yuzyk (1973:38) credited another American, Charles Hobart, a sociologist, as being the first to use the term multiculturalism in the discourse to describe the most recent and enduring metaphor for tolerance and acceptance of diversity in Canadian society. Whereas Hayward's mosaic stood in contrast to the melting pot of her day, Hobart's multiculturalism contrasted the American melting pot ideal in his day. Since Hobart coined the term, Canadian multiculturalism has frequently been referred to as an ideology. Dorothy Emma Moore (1980), Rodney A. Clifton and Lance W. Robetts (1981), Evelyn Kallen (1982), Kogila Moodley (1983), B. Singh Bolaria and Peter S. Li (1985) and Jean Leonard Elliott and Augie Fleras (1990), to mention a few have all made that reference. As an ideology, however, it has experienced a notable transformation. As I trace this evolution of an ideology, I expect we will see even further transformations in the new millennium.

Multiculturalism in Canada since the 1960 s was initially theoretically conceptualized in terms of ethnic and race relations (Burnet, 1975,1983; Patel, 1980). The ethnic relations perspective dominated the 1970s; the race relations problematic emerged in the 1980s; the political economy approach was added for the 1990s. The differences in the throe above-mentioned fomulations of multiculturalism can be compared to the way we can talk about the daily temperature e.g. Fahrenheit and Celsius scales and the later developments of 
the wind chill, humidex, or ultraviolet nisk factor weather indicators. For instance, the proponents of the race relations school in the 80 s argued that their treatment of discrimination and racism are additional factors to which ethnic relations does not give due recognition. In a similar fashion, the political economy school emphasizes the economic, political and ideological dimensions in Canadian society which must be considered in any analysis and evaluation of multiculturalism policy in Canada.

Furthermore, numerous histories on various groups in Canadian society, using the ethnic relations approach, missed a systematic discussion of how ethnic and racial groups have been allocated into their various positions in the economic, political and ideological spheres of Canadian society. Cultural comparisons are often drawn between various ethnic and racial groups. However, when we abstract the cultural universals in ethnic relations and focus on function, we have an ahistorical treatment of migration to Canada. From a political economy perspective, the context in which race relations situations occur is missing.

Historically, the ethnic relations paradigm dominated analysis of multiculturalism in Canada Jean Bumet (1975) described the government's policy of ethnic relations as being multiculturalism within a bilingual framework. This policy she argued, however, did not have a clear mandate regarding immigration and racism.

Spokesmen who pressed hardest for a policy of multiculturalism did not concem themselves ovennuch with the situation of rocent immigrants in Canada (1975:37).

Burnet pointed out that, structurally, multiculturalism has been historically dealt with by the Secretary of State while immigration has been under the auspices of another department. It is thus understandable that the first study commissioned under the policy of multiculturalism was one on non-official languages (Bumet, 1983:239). While the work by O'Bryan, et al. (1976) does refer to immigration phases, and considers the context briefly, it is primarily concemed with cultural (language) retention. Given the nature of immigration up to that time, no issues of racial discrinination were raised Yet it is just these kinds of human rights rather than collective cultural rights of the other ethnic groups that were of utmost concem to new immigrants from the Third World. Bumet asserted that

the policy of multiculturalism within a bilingual framework is handicapped by its name and by its lack of unambiguous conceptualization in dealing with its critics and with the new ethnic composition of the population (Bumet, 1983:241).

Raymond Breton (1979, 1980), Jean Bumet (1983), Leo Driedger (1978, 1989) and Jean Elliott (1983) best represent the ethnic relations school of thought. Politically, the ethnic relations approach is best represented by the 1970 Report of the Royal Commission on Bilingualism and Biculturalism, especially Book IV: The Cultural Contribution of the Other Ethnic Groups. In fact, Jean Bumet is credited with the writing of that report (Palmer, 1991). 
In addition, the ethnic relations approach to multiculturalism dominated the 1970s political climate and to a degree into the 1980s. For example, Sheridan (1989) did not cite even one author from the race relations school of thought. His historical background paper on Canadian Multiculturalism by the Library Research Branch of Parliament was especially prepared for Members of Parliament. In contrast, the work of Patel (1980) within the departmental bureaucracy and the situation reports on race relations commissioned by the Minister of State for Multiculturalism for Canada informed the 1984 Equality Now! report produced by the Special Parliamentary Committee on the Participation of Visible Minorities in Canadian Society.

The Equality Now! Report was the first major report to identify and define what was meant by the term, visible minorities.

For the purposes of this report, visible minorities have been defined as non-whites who are not participating fully in Canadian society. The approximate non-white population of Canada is $1,864,000$ or 7 per cent of the population. These figures include the aboriginal people, Canadians with origins in Africa, Arab countries, China, India, Pakistan, Japan, Korea, South East Asia, Latin America, the Pacific Islands, the West Indies, and the Philippines (Equality Now!, 1984:2).

The Special Parliamentary Committee on the Participation of Visible Minorities in Canadian Society was a milestone report in that it provided a voice for the marginalized and those who had experienced discrimination. The Committce made itself available and approachable to the entire country. By traveling and holding hearings in all parts of Canada, those who would not nomally be able to come to Canada's capital in Ottawa, could still be heard.

To ensure that the Canadian public was informed about its work, the Committee placed advertisements in major daily newspapers across the country. The last advertisement was placed just prior to its anival in major citics. The Committee received hundreds of letters; approximately 300 briefs were sent to Ottawa and a 130 groups of witnesses were heard in Ottawa, Halifax, Montreal, Toronto, Winnipeg, Regina, Yellowknife, Whitehorse, Edmonton and Vancouver. The Minister of Justice and the Minister of Multiculturalism testified before the Committee. The Committee also actively solicited information from other sources, both private and public (Equality Now!, 1984:6)

Third World immigration into Canada led Canadian scholars to deal with issues of racism and discrimination. The race relations paradigm as imported from Great Britain into Canada in the 1980s was the dominant paradigm for analyzing race and ethnic relations in the United Kingdom. Academically it had been institutionalized into many Canadian 
university course offerings in sociology. Politically race relations issues have increasingly appeared on govemmental agendas (Miles, 1982:1, 20). However, from the political economy perspective, race relations studies do not adequately account for the total context in which race relations situations occur. The race relations problematic with its focus on race as a key operational variable in race relations does not develop systcmatically the economic, political and ideological relations that stucture racism and discrimination. Miles (1982:43) asserts that

the analytical task is...neither to try to locate a place for a concept of 'race' in some theory nor to try to develop a theory of 'race relations' but to identify the conditions for the generation and reproduction of the idea of 'race', which is to explain why certain sorts of situation and relations appear (i.e. are socially constructed) as 'race relations'

Theoretically, the race relations perspective in Canada which informed the govemment of the day and provided some direction for parliamentary committees was the report by Dhiru Patel (1980). Additionally, there were situation research studies done in eleven cities across Canada dealing with race relations (Equality Now!, 1984:4). Politically, the race relations approach is best represented by the Equality Now! report that was tabled in the House of Commons in May, 1984. This was within the parliamentary domain of the Minister of Multiculturalism. A complementary effort, the Abella Royal Commission Report on Equality in Employment which focuses on employment equity for visible minorities, was the responsibility of the Minister of Employment and Immigration. Employment equity is the Canadian equivalent of affirmative action in the United States that encompasses not only visible minorities as immigrants but also Canada's indigenous population. This report was published later in October, 1984.

The Special Parliamentary Task Force on the Participation of Visible Minorities in Canadian Society, that produced the report Fquality Now!, in some ways served as a catalyst to expand the horizons of multiculturalism ideology within Canadian society. The report highlighted the fact that the Canadian perception is that compared with other countries, Canada has positive reputation in the area of race relations. No laws or rules in institutions setm to deny equality of opportunity for visible minorities. Many studies seem to affirm that Canadians are not racists. However, the report proceeded to acknowledge that Canada has flaws, nonetheless.

Research has shown that as many as 15 per cent of the population exhibit blatantly racist attitudes, while another 20-25 per cent have some racist tendencies. Moreover, even those individuals who are very tolerant can, with the best of intentions, engage in racism without knowing it or meaning to do so. Similarly, institutions can 
unintentionally, restrict the life chances of non-white individuals through a variety of seemingly, neutral rules, regulations and procedures (Equality Now!, 1984:3).

Thus we can see where Parliamentary Committees have also had a role to play in pushing Canadian multicultural ideology towards full acceptance of all minorities.

The political economy approach, illustrated by B. Singh Bolaria and Peter Li (1985), Frances Abele and Daiva Stasiulis (1989), Vic Satzewich (1988, 1989), Miles (1988, 1993) and Wallace Clement and Glen Williams (1989) is an altemative attempt to understand ethnic and race relations in Canarla. From a scholarly perspective, it is interesting to note that those who have written from within the ethnic relations school of research have tended to deal with multiculturalism as a positive policy of tolerance. They have defended the policy and have written about various ethnocultural groups which have integrated into Canadian society. On the other hand, the race relations school of writers are critics who have tended to oppose multiculturalism as a policy because its focus on culture has neglected the issues of racism and discrimination within a policy of tolerance. Politically the $B \& B$ Report as well as the Equality Now! report propelled the policy of multiculturalism into the public arena for debate. Academic and, in a contrasting way, political intellectuals have grappled with the institutionalized transformation and resilience of multiculturalism in spite of its rejection by those who adhere to the dominant ideology of bilingualism and biculturalism (Fleras and Elliott, 1992, 2002).

The political function of this multiculturalism discourse has frequently been perceived as an attempt to placate and entice ethnic votes under the guise of tolerance. However, with a change in immigration from the traditional source of European countries to various Third World ones, a new reality emerged. The new immigrants, usually identified as visible minorities had different priorities on their agendas.

The sensitivity of the federal government to the new ethnic situation was evident in late 1975 when... the Hon. John Munro, announced that henceforth priority would be given to group understanding and the combating of discrimination rather than cultural survival (Bumet, 1983:241).

The new demographic presence of visible minorities in Canadian society, coupled with the erstwhile ignored Native Aboriginal Canadians, as well as groups such as the Blacks of Nova Scotia, was reflected in the discourse before the Special Parliamentary Committee on the participation of Visible Minorities in Canadian Society and in its report Equality Now! The discourse and the title of the report incorporates the notion of an idea plus action, not only mere tolerance but also full acceptance into Canadian society. Patel's research on 'race relations' argued that the notion of multiculturalism must be transformed if new realities were to be accommodated. 
As conceived of and implemented at present, the policy of multiculturalism... simply recognizes and legitimizes, for example East Indian cerernonies and Ukrainian dances, nothing more. (Patel, 1980:36,38,39).

Tolerance is confined to cultural activities. The possibility of multiculturalism ideology being transformed was explicitly recognized and acknowledged by Patel as early as 1980 .

...if the idea of multiculturalism is to mean more than just 'ethnic' ceremonies and dances, then it has to incorporate an important if not substantial element of genuine power sharing at all levels (Patel, 1980:60).

The discourse of the recommendations in Equality Now! and various situation reports as well as research for the Parliamentary Committee considered the structural aspects of multiculturalism policy. Issues of racism were consciously incorporated as a result of research and hearings across the country.

Upon assuming office in 1984, the Mulroney government embarked upon an exercise of adopting a business approach to all govemment operations. The new Conservative government announced that their new policy of 'mainstreaming multiculturalism' (Lewycky, 1986:14) would replace the old Liberal one. In 1986, with a new Minister of Multiculturalism, the govemment held a Multiculturalism and Business Conference in Toronto. Therefore, as far as the government policy on multiculturalism was concemed: 'Multiculturalism means Business!' (Lewycky, 1986:15). The ideology of letting the free market determine all government activities was reflected in the Nielsen report commissioned by the Mulroney government. Cultural and discrimination issues took a back seat.

\section{Race Relations and Racism}

New definitions were shaped by new historical contexts raising the issue of race relations and racism. The influx of visible minority immigration into Canada during the 1970s and the 1980s provided a new demographic dimension and, given the fact of universal suffrage, a new political context for the report Equality Now! These new political constraints further changed the discourse in the ideology of multiculturalism. Since ideology is not a static phenomenon, we can understand this aspect of dynamic in the notion of multiculturalism. The critique that Peter Li gives with regards to a 'culture approach' to the study of ethnic and race relations is the frequent type of critique given to the Standing Committee that wrote Equality Now!

Among the strongest critics of the misuse of the concept of culture is Valentine (1968) who pointed out a potential tautology in using culture as a description and an 
explanation...approach to culture is mainly static. Culture is often secn as primordial and etemal...This primordial culture is monolithic, and the cultural heterogeneity of the home country is rarely considered $(\mathrm{Li}, 1988: 35,28)$.

If multiculturalism is not perceived in restrictive cultural terms, but rather as a dynamic ideology, a different understanding arises.

Most of the scholarly work in this area has involved studies of individual ethnic communities and ethnic relations...intemal debate about the nature of multiculturalism - the only one in Canada - expressed mainly in joumal articles and conference dissertations, has taken place among Canadian sociologists and several other academic specialists in recent years. With only a few notable exccptions, however, this debate reveals a considerable ignorance of or disinterest in its political dimensions (Hawkins, 1989:227).

Sazzewich (1991) underlined the fact that the state sometimes prohibits the entry of certain individuals into Canadian society. He has documented ways in which non-whites have been precluded from entry into Canada. Similarly, we can recall Liberal Prime Minister Mackenzie King's desire to exclude Jewish immigrants. For other immigrants the state plays the role of facilitating their entry. This political dimension in the tolerance or acceptance of the other into Canadian society requires further attention. One of the lacunae in the political process has been an adequate understanding of the role of parliament and Members of Parliament in this whole process. I want to point out some specific political parliamentary dimensions to immigration, ethnicity and race relations. While there are important economic constraints upon govemment that must be recognized, the govemment does have a relative autonomy in choosing courses of action vis-à-vis race and ethnic relations delineated above. The nature of a parliamentarian's role has undergone substantial transformation (Lewycky, 1989:240-259). The Member of Parliament is now considered to be a full time professional with staff who can be expected to take on an increasing responsibility for immigration and race relations concems as part of the political agenda A parliamentary committee was an institutionalized structure for addressing such matters. In addition there are other political institutions such as caucuses which can liberate or constrain state involvement in racial inequalities. Regardless, in the Canadian experience, however, individual parliamentarians have also played a significant role in pushing the ideology of multiculturalism towards a more inclusive full acceptance rather than mere tolerance of ethnocultural diversity.

One major development anising from the Equality Now! report, the outcome of a Special Parliamentary Committee on the Participation of Visible Minorities in Canadian Society, was the establishment of a Permanent Standing Committee on Multiculturalism in the House of Commons. On Friday, June 28, 1985, the Federal Govemment implemented Recommendation 26 that called for the establishment of a Committee on Multiculturalism. 


\section{Ethnic Studies Review Volume 30: 1\&2}

The idea for a Standing Committee on Multiculturalism was first raised in the House by the Multiculturalism Spokesperson for the New Democrotic Party on December 9, 1983 (Lewycky, Hansard). Canada with its multiple party parliamentary system is conducive for initiating political change or enhancing the expansion of public policy such as the embracing of a more inclusive multiculturalism ideology of full acceptance. Numerous ethnocultural and visible minority organizations had indicated that such a permanent forum would provide a means for monitoring progress in the area of race relations. The Conservative Mulroney govemment in its second tem of office briefly disbanded this committee. However, the public outcry that resulted forced the government to reconsider its actions and restore the committee. In this way the pressure exerted by ethnocultural and visible minority groups were a significant factor in broadening multiculturalism ideology beyond mere tolerance.

The tems of reference for the Standing Committee on Multiculturalism stated that the permanent order of reference for the Standing Committee on Multiculturalism be as follows:

that the Committee be empowered to encourage and monitor the implementation of the principles of the federal multicultural policy throughout the govermment of Canada, and in particular, (1) to encourage the departments and agencies of the federal govemment to reflect the multicultural/multiracial diversity of the nation, and (2) to examine existing and new programs and policies of federal dcpartments and agencies to encourage sensitivity to multicultural concems and to preserve and enhance the multicultural/multiracial reality of our nation, and:

that the Committee be authonized to select and initiate subjects for investigation within their jurisdiction and to prepare background papers, reports and research in this regard.

That such changes did follow can be documented by the fact that this committee had worked towards the introduction of a Multiculturalism Act in 1988, and was involved in the bill which would re-structure the Department of the Secretary of State which is responsible for defining and dealing with citizenship. Members of Parliament are in a representative role vis-à-vis their respective constituencies. However, even there they do possess a relative autonomy when elected and in their capacities as M.P.'s. Likewise, even though their political parties and caucuses may constrain them, there is a degree of relative autonomy in that area as well. Thus the 1984 Equality Now! Report was able to pave the way for groups seeking rodress, such as the Japanese Canardians. Justice, an ethical multiculturalism issue of tolerance and acceptance, meant that the War Measures Act that had been raised during the 1970 October crisis was revisited. The minority view during World War II as expressed by the Cooperative Commonwealth Federation (CCF) Member of Parliament, and later the leader of the New Democratic Party (NDP), Tommy Douglas and his plea for tolerance and acceptance in Canadian society was given a second look. This third party phenomenon in the 
Canadian parliamentary govemance has consistently played a progressive role in expanding the ideology of multiculturalism into becoming more inclusive.

Subsequently issues of citizenship gained more prominence and it seemed that multiculturalism was being submerged by a value of citizenship (Fleras and Elliott, 1999). World conflicts, however, such as those in the forner Yugoslavia and parts of Africa as well as the Middle East again have thrust the underlying value of tolerance and acceptance as exhibited in the ideology of multiculturalism to the forefront. The 2001 World Conference against Racism in Durban, South Africa was another such focus.

\section{Triumph of Terrorism or the Triumph of Tolerance and Acceptance}

Richard Day (2000) traces Canadian diversity to the ancient antecedents that can be found in discourses of Plato and Aristotle. He argues that a state-sponsored multiculturalism has become a failed solution which is trapped in a fantasy of unity. All of these issues of diversity, however, were singularly eclipsed by the temorist attack of September 11, 2001 in New York. The media brought to our attention the stark reality of that tragic event. Further, media shapes not only our perceptions of world situations but also our ideological responses and strategies for dealing with issues of immigration, race relations and racism. The media places certain issues on the agenda. Griffin (2000) has noted in his covering of the agendasetting theory that its history and scope varies from the limited effects model of the early founders to the more powerful version espoused by Maxwell McCombs and Donald Shaw. Given the influence of the media gatekeepers in terms of what the viewers see, it is interesting to observe the political responses to the coverage of the events of September 11,2001 and the subsequent treatment of visible minorities in society.

Canadian Multiculturalism, albeit state supported, has emerged as our ideological metaphor for tolerance and acceptance as an antidote for our history of intolerance. Politically, in Canada, in the wake of September 11, 2001, only minority parties were highlighting the necessity for caution and urging tolerance and even more so acceptance of ethnocultural and racial diversity. Canada has had its share of intolerance, such as the expulsion of the Acadians in 1755, part of the history of the Maritimes. We must leam from our own Maritime history that intolerance can be overcome and through tolerance and acceptance, a rich legacy of equality and justice can be bequeathed to the next generation. From a political perspective, as the demographics of the Maritimes and Canada are examined, Canada requires a substantial increase in immigration if the decline in population is to be reversed. This immigration source, as our history as shown since the $1960 \mathrm{~s}$, is no longer the European continent. Instead all of Canada and not just the Maritimes will have to rely on immigration from source countries that bring into the Canadian context, increased numbers of visible minorities. 


\section{Ethnic Studies Review Volume 30: 1\&2}

Multiculturalism as an ideological metaphor for not only mere tolerance but also full acceptance may yet prove to be as an enduring symbol for the Canadian ideology of managing diversity within our borders. Why is it that Canada has appanently been willing to embrace an ideology of multiculturalism that goes beyond mere tolerance to full acceptance? This paper has traced various factors that have contributed to the direction that the ideology of multiculturalism has evolved. The changing demographics of an immigrant receiving country has forced the hand of Canada's Anglophone and Francophone hegemonic charter groups to adopt a more hospitable approach to managing diversity within Canadian society. These ethnocultural groups and their organizations have at various times exerted their political pressure, given their voting clout, to expand the hoizons of Canada's policies of inclusion in the body politic. Individual scholars and parliamentarians in important Royal Commissions and Parliamentary Committees have had significant input into the transformation of multiculturalism ideology. Canada's historical bilingualism and biculturalism of the two charter groups in contrast to the monoculturalism of its neighbour to the south, has ideologically provided space for expansion from biculturalism to multiculturalism. Added to this has been the bipartisanship suppoit that has developed from the two major goveming parties - Liberals and Conservatives. Also the impetus for change, innovation and progress has been provided by the third and multiple party phenomena in Canadian politics. This parliamentary influence has had an impact on the ideology of multiculturalism. Perhaps the single most important contributing factor has been the impact of the milestone report Equality Now! which acted as a catalyst to force multiculturalism ideology to incorporate a response not only to prejudice and cultural diversity but also issues of racism as well as individual and institutional discrimination within Canada's seemingly tolerant society.

Around the world, the maple leaf on our flag is our symbol of Canada as a peace loving nation of shalom. As we recall the acrimonious flag debates of the early $1960 \mathrm{~s}$, so we can recall all the current controversial debates about multiculturalism. Just as the maple leaf has become institutionalized politically as our visible symbol of shalom and welcome so too multiculturalism has become institutionalized as our invisible ideological symbol of full acceptance of our diversity. Canadian multiculturalism ideology is being transformed from a memory of multiculturalism as tolerance, to the place of multiculturalism in society as the potential beacon for the value of full acceptance in Canadian society. Even the new current Conservative government of Stephen Harper has jumped on the multiculturalism bandwagon. Prime Minister Stephen Harper recently officially offered a full apology for the notorious Head Tax imposed on Chinese immigants entering Canada between 1885 and 1923. In addition, the Govemment of Canada made symbolic ex-gratia payments to those who are still alive and were required to pay the Head Tax or their surviving spouses. Furthermore, Canada will fund national and community projects regarding the impact of past wartime measures and immigration restrictions on ethno-cultural communities. Will multiculturalism survive? Will the threats of teronism or globalization in a post-modem 
world obliterate multiculturalism? Post-modem society secms to favour pluralism. It would seem that postmodemity should be a conducive context to maintaining the new transformed multiculturalism ideology which increasingly seems to embody the notion of full acceptance not mere tolerance.

\section{SELECT BIBLIOGRAPHY}

1985 Bolaria, B. Singh and Peter S. Li. Racial Oppression in Canada. Toronto: Garamond Press.

1980 Breton, Raymond, Jeffrey G. Reitz, and Victor F. Valentine Cultural Boundaries and the Cohesion of Canada Montreal: Institute for Research on Public Policy.

1979 'Ethnic Stratification Viewed from Three Theoretical Perspectives' pp. 270-294 in James E. Curtis and William G. Scott, Social Stratification: Canada (Second Edition) Scarborough: Prentice-Hall of Canada, Ltd.

1979 Brown, J Lloyd G. Parables of Life in Shakespeare. Hantsport, Nova Scotia: Lancelot Press.

1987 Bumet, Jean. "Multiculturalism in Canada." in Driedger, Leo (ed.), Ethnic Canada: Identities and Inequalities. Toronto: Copp Clark Pitman, pp. 65-79

1983 'Multiculturalism 10 Years Later.' in Jean Leonard Elliott (ed.), Two Nations, Many Cultures. Scarborough, Ontario: Prentice-Hall Canada Inc. pp. 235-242

1988 Bumet, Jean R with Howard Palmer.Coming Canadians: An Introduction to a History of Canada's Peoples. Toronto: McClelland and Stewart

1970 Report of the Royal Commission on Bilingualism and Biculturalism. Book IV: The Cultural Contribution of the Other Ethnic Groups. Ottawa: Queen's Printer.

1989 Clement, Wallace and Glen Williams (eds.). The New Political Economy. Kingston: McGill-Queen's University Press.

1981 Clifton, Rodney A., and Lance W. Roberts. "Exploring the Ideology of Canadian Multiculturalism," Canadian Public Policy 8(1):88-94. 


\section{Ethnic Studies Review Volume 30: 1\&2}

1989 Driedger, Leo.The Ethnic Factor: Identity in Diversity. Toronto: MoGraw-Hill Ryerson Limited.

1989 Dwivedi, O.P., Ronald d'Costa, C. Lloyd Stanford, and Elliot Teppor. Canara 2000: Race Relations and Public Policy. Guelph: Dept. of Political Studies, University of Guelph.

1983 Elliott, Jean Leonard Two Nations, Many Cultures, (Second Edition). Scarborough: Prentice-Hall Canada, Inc.

1999 Eleras, Augie and Jean Leonard Elliott. Unequal Relations: An Introduction to Race and Ethnic Dynarnics in Canada. Scarborough: Prentice-Hall Canada Inc.

1926 Foster, Kate. Our Canadian Mosaic. Toronto: Dominion Council of the Y.M.C.A.

1982 Frye, Northrop. The Great Code. Toronto: Academic Press.

1938 Gibbon, John Murray. Canadian Mosaic: The Making of a Northem Nation. Toronto: McClelland \& Stewart Limited.

2000 Griffin, Em. A First Look at Communication Theory. Boston: MoGraw-Hill.

1989 Hawkins, Freda. Critical Years in Immigration; Canada and Australia Compared Montreal: MoGill-Queen's.

1922 Hayward, Victoria. Romantic Canada. Toronto: The MacMillan Company of Canada (in collaboration with Edith Watson).

1988 House of Commons Bill C-93 Canadian Multiculturalism Act (Passed by the House of Commons July 12).

1984 House of Commons, Special Parliamentary Committee on the Participation of Visible Minorities in Canadian Society Equality Now. Ottawa: Supply and Services. House of Commons.

1992 Lewycky, Laveme. Multiculturalism in the 1990s and into the 21st Century: Beyond Ideology and Utopia" in Vic Satzewich, ed. Deconstructing a Nation: Immigration, Multiculturalism and Racism in '90s Canada Halifax, Nova Scotia: Femwood Publishing. 
1991 "Race Relations: Retrospect and Prospect" in Harish Jain, et al (eds.) Equality For All, National Conference on Racial Equality in the Workplace: Retrospect and Prospect. Hamilton, Ontario: McMaster University and Industrial Relations Research Association.

1989 _Politics, Race Relations and Public Policy" in O.P. Dwivedi, Ronald d'Costa, C. Lloyd Stanford, and Elliot Tepper Canada 2000: Race Relations and Public Policy. Guelph: Dept. of Political Studies, University of Guelph.

1986 _Canadian Ethnic Identity: Visions and Revisions." (CREME Working Paper \# 7), Ottawa: Center for Research on Ethnic Minorities, Etc., Department of Sociology and Anthropology, Carleton University.

1988 Li, Peter S. Ethnic Inequality in a Class Society. Toronto: Wall \& Thompson.

1983 Li, Peter S. and B. Singh Bolaria. Racial Minorities in Multicultural Canada. Toronto: Garamond Press.

1993 Miles, Robent Racism after 'race relations'. London: Routledge.

1983 Moodley, Kogila. "Canadian multiculturalism as ideology" in Ethnic and Racial Studies, 6(3) July: 320-331.

1980 Moore, Dorothy Emma. Multiculturalism - Ideology or Social Reality? Unpublished doctoral dissertation, Boston University.

1976 O'Bryan, K.G., J.G. Reitz, and O.M. Kuplowska. Non-Official Languages - A study in Canadian Multiculturalism. Ottawa: Supply and Services Canada.

1976a Palmer, Howard. "Mosaic versus Melting Pot?': Immigration and Ethnicity in Canada and the United States," Intemational Joumal, XXXI, No. 3, Summer, 1976.

1976b "Reluctant Hosts: Anglo-Canadian Views of Multiculturalism in the Twentieth Century." Multiculturalism as State Policy: Confenence Report, Second Canadian Conference on Multiculturalism, 88-113. Canadian Consultative Council on Multiculturalism. Ottawa: Supply and Services.

1973 Palmer, Howard and Harold Troper. "Canadian Ethnic Studies: Historical Perspectives and Contemporary Implications." Interchange, Vol. 4, No. 4, Toronto: Ontario Institute for Studies in Education. 


\section{Ethnic Studies Review Volume 30: 1\&2}

1980 Patel, Dhinu. Dealing with Interracial Conflict: Policy Altematives. Montreal: Institute for Research on Public Policy.

1965 Porter, John. The Vertical Mosaic. Toronto: University of Toronto Press.

1992 Satzewich, Vic. Deconstructing a Nation: Immigration, Multiculturalism and Racism in '90s Canada. Halifax, Nova Scotia: Femwood Publishing.

1989 Sheridan, William. Canadian Multiculturalism. Ottawa: Library of Parliament.

1984 Special Parliamentary Committee on the Participation of Visible Minorities in Canadian Society Equality Now! Ottawa: Supply and Services.

1990 Stasiulis, Daiva Kristina. Theorizing Connections: Gender, Race, Ethnicity, and Class" in Peter S. Li, (ed.) Race and Ethnic Relations in Canada. Toronto: Oxford University Press.

1990 Ujimoto, K. Victor. "Studies of Ethnic Identity and Race Relations" in Peter S. Li, (ed.) Race and Ethnic Relations in Canada. Toronto: Oxford University Press.

1980 Valentine, Victor. 'Native Peoples and Canadian Society: A Profile of Issues and Trends" in Breton, Raymond, Jeffrey G. Reitz, and Victor F. Valentine. Cultural Boundaries and the Cohesion of Canada. Montreal: Institute for Research on Public Policy.

1972 Woodsworth, J.S. My Neighbour. Toronto: University of Toronto Press.

1972 Strangers Within Our Gates. Toronto: University of Toronto Press

1973 Yuzyk, Paul. For a Better Canada. Toronto: Ukrainian National Association, Inc. 